\title{
Remineralization of Carious Dentin. I: In Vitro Microradiographic Study in Human Teeth Capped by Calcium Hydroxide
}

\author{
Carlos Alberto CONRADO \\ Department of Dentistry, State University of Maringá (UEM), Maringá, PR, Brazil
}

\begin{abstract}
The objective of this in vitro study was to evaluate a possible remineralization of human carious dentin by calcium hydroxide. Thirtynine freshly extracted human permanent and deciduous carious teeth were split into two halves. One half was used as control and the other as experimental. In the latter, a cavity was prepared and the remaining bottom layer of demineralized dentin capped with chemically pure calcium hydroxide. The experimental samples were stored at $37^{\circ} \mathrm{C}$. Time intervals were $2,4,6,8,10$ and 12 weeks. All tooth halves were sawed and ground to plano-parallel sections with a thickness varying from 75 to $117 \mu \mathrm{m}$. Qualitative microradiographs showed a qualitative increase in radiopacity of the calcium hydroxide treated samples. Quantitative microradiography showed a statistically significant increase in total mineral content in the experimental samples compared to the control samples. These results indicate an in vitro remineralization of carious dentin by calcium hydroxide.
\end{abstract}

Key Words: carious dentin, calcium hydroxide, carious dentin remineralization.

\section{INTRODUCTION}

The first author to suggest that carious dentin could be rehardened in a similar manner as enamel was Head (1), in 1912. Calcium hydroxide was employed in the present study as the possible remineralizing agent on account of several previous reports by Conrado $(2,3)$ in 1994, demonstrating clinically, radiographically and histologically its rehardening capacity when applied over a layer of sound or carious dentin, as well as other beneficial properties.

Several clinical and radiographic studies advocating the philosophy of leaving a layer of carious dentin capped with calcium hydroxide in deep cavities where pulp exposure would be highly probable reported increased radiopacity after treatment and harder dentin (4-7). Other authors have shown evidence of carious dentin remineralization of the same deep remaining layer, by means of different methodologies and utilizing several materials, including calcium hydroxide (8-13).

Thus, the objective of this study was to evaluate qualitatively and quantitatively the occurrence of remineralization in carious human teeth in vitro after capping with calcium hydroxide.

\section{MATERIAL AND METHODS}

Thirty-nine freshly extracted carious human teeth (22 permanent and 17 deciduous) selected at random were utilized in this study. No detailed criteria were established to classify the carious process according to depth or degree of softening or hardening. The single criterion used was that the teeth ought to present reasonably deep carious lesions but not encroaching clinically on the pulp tissue.

Each tooth was split into two halves with a diamond disc to provide an experimental sample and a control sample. Each experimental half was placed in an acrylic container prior to experimentation with its root immersed in methylmethacrylate and its crown made visible and immobile. Conventional cavity preparation was carried out and the remaining bottom layer of demineralized dentin was capped with a mixture of chemically pure calcium hydroxide and distilled water. Each half was then transferred to a glass container with

Correspondence: Prof. Dr. Carlos Alberto Conrado, Clínica Odontológica, Departamento de Odontologia, Universidade Estadual de Maringá, Av. Mandacaru 1550, Bloco Sø8, 87013-010 Maringá, PR, Brasil. Tel/fax: +55-44-224-3633. e-mail: caconrado@wnet.com.br 
sterile distilled water in the bottom to maintain the specimen in a humid atmosphere during the observation period and stored at $37^{\circ} \mathrm{C}$. Each control half was stored in a test tube with $70 \%$ alcohol until the end of each interval.

After time intervals of $2,4,6,8,10$ and 12 weeks, both halves of each tooth were processed histologically to obtain longitudinal ground sections. The tooth halves were electrically sawed and an average of six sections of approximately $300 \mu \mathrm{m}$ in thickness were obtained with the aid of a diamond-saw microtome (Hammarlund-Essler, Stockholm, Sweden). The final grinding and polishing to attain desired thickness were performed mechanically according to Ericsson's (14) method utilizing a high capacity grinding microtome (Seastrand/Original-Müller-Tempo, Stockholm, Sweden) thus rendering the sections plano-parallel and ready for qualitative and quantitative microradiography.

The ground and polished sections were placed in contact with a photographic emulsion (Kodak Plate Maximum Resolution) and exposed to ultra-soft x-rays of low penetration power for $10 \mathrm{~min}$ in a diffraction tube (Philips 25 292/52). Qualitative microradiographs of the same size of the sections were then obtained. Differences in X-ray absorption of the ground sections of treated and untreated halves were evaluated qualitatively by means of a light microscope (Leitz). Photographic enlargements of the sections of $10 \mathrm{X}$ and $20 \mathrm{X}$ magnifications were obtained for orientation and determination of the areas to be quantitatively measured later. Four areas to be compared were chosen for each section at four identifiable points in both experimental and control halves: two at the superficial area that was in closer contact with the calcium hydroxide, one located at a deeper area closer to the pulp and one at an area of unaffected sound dentin.

Quantitative microradiography of the ground sections was undertaken following the specifications of Ericsson (14) and Bergman (15), by means of a suitable reference system consisting of a stepwedge arrangement of aluminum foils placed on the emulsion close to each specimen exposed to ultra-soft x-rays for $40 \mathrm{~min}$.

The exact thickness determinations needed for quantitative microradiography were performed for the four predetermined areas of each ground section, measured by means of a precision micrometer (Microcator C.E. Johansson/Eskilstuna, Stockholm, Sweden) al- lowing the reading down to $0.5 \mu \mathrm{m}$. Determinations of absolute amounts of mineral content of a microscopic area measured in a specimen were calculated according to Ericsson's (14) formula. It must be emphasized that each two sections compared (experimental and control) were from the same area of the tooth, of approximately the same thickness and submitted to the same exposure and developing times, thus rendering it possible to record quantitative data related to tissue mass and to accurately establish absolute determinations of differences in mineral content expressed in percentages by volume of two comparable microscopic areas within the same tooth.

\section{RESULTS}

Qualitative assessment of the microradiographs taken for 78 samples (39 calcium hydroxide-capped and 39 control) showed, by examination with a light microscope, an increase in the radiopacity of the treated samples, in the great majority of cases. This strongly indicates that a remineralization process induced by calcium hydroxide had occurred.

Quantitative assessment: thickness measurements ranging from 75 to $117 \mu \mathrm{m}$ (with an average of $98 \mu \mathrm{m}$ ) and photometric measurements were performed for a total of 312 areas, 4 for each sample examined. Applying Ericsson's formula (14), the total mineral content in percentage by volume was determined for all areas measured. Results revealed that for all of the 234 treated and untreated carious areas (the other 78 areas from a total of 312 were from sound dentin), except two, experimental samples showed an increase in total mineral content compared with control samples. The average mean of total mineral content before treatment was $13.87 \%$ (range $0-42.99 \%$ ) and after treatment $32.70 \%$ (range $2.25-57.24 \%$ ).

Analysis of variance and an $\alpha$ test based on average means showed a statistically significant difference at the 5\% level in the increase in total mineral content between experimental and control samples, favoring the experimental ones.

A comparison was made to determine if there was any relationship between the application of calcium hydroxide and the different intervals of time. Analysis of variance, a linear model and a $\beta$ test showed no statistically significant differences at the 5\% level.

The results of a comparison between superficial 
and deep areas measured in the treated samples regarding their total mineral content showed that the average mean of increase after the application of calcium hydroxide was $34.57 \%$ for the two superficial areas and $26.31 \%$ for the deeper area. Statistical analysis revealed a significantly higher difference for the superficial areas (t-test, $5 \%$ ).

Another comparison was made to determine if there were any statistically significant differences in the increase of the total mineral content between the 22 permanent and the 17 deciduous teeth, the average mean found being $33.81 \%$ for permanent teeth and $31.10 \%$ for deciduous. No significant differences between the two dentitions were found using analysis of variance that included fixing levels and two Tukey tests.

\section{DISCUSSION}

Qualitative assessment of microradiographs examined in the present study showed a marked increase in radiodensity related to the great majority of samples of carious dentin capped with chemically pure calcium hydroxide, as compared with control samples, thus indicating that a remineralization process took place. The qualitative interpretation was confirmed for every case by analyzing the results of the quantitative microradiographic data.

The remineralization process induced by calcium hydroxide seen in the present study was more significant regarding the quantitatively measured areas in closer contact with the remineralizing agent, even though it also penetrated into deeper areas. The remineralizing effect observed in carious dentin treated by calcium hydroxide was evident even in those samples in which almost all of the mineral content had suffered a complete demineralization by the carious process. The total mineral content of many of the samples after remineralization closely approached the absolute quantitative values found for sound dentin areas measured within the same samples.

The mineral content values found for sound dentin as quantitatively determined are in agreement with those found through the same method by Ericsson (14). By comparing the remineralization behavior of permanent and deciduous teeth, no statistically significant differences were found. Differences related to the six different intervals of time were also statistically non-significant. Thus, we can conclude that a period of two weeks was sufficient to promote remineralization of carious dentin capped with calcium hydroxide, in vitro.

This investigation did not reveal either the nature or the mechanism of the process involved in the in vitro remineralization. Mjør (16) considered that, if remineralization occurred following the application of calcium hydroxide in extracted teeth as well as in vivo, it becomes clear that the role of the pulp in the process could be questioned and may be excluded as a significant factor when trying to explain the mechanism of action of calcium hydroxide. The mechanism involved is probably of a physicochemical nature, as suggested by Mjør (16).

Mondelli (17) stated that, since calcium hydroxide is particularly effective in stimulating the formation of reparative tertiary dentin, it is the material of choice for use in very deep cavities, particularly in those situations in which the possibility exists of microexposures of the pulp that are not clinically detected. Koch et al. (18), McDonald and Avery (19) and Mathewson and Primosch (20) also recommended calcium hydroxide, based on similar reasons.

To our understanding, the main clinical application of this investigation relates to the philosophy of indirect pulp capping, not removing and capping with calcium hydroxide the last layer of demineralized and largely uninfected and remineralizable dentin closer to the pulp.

\section{RESUMO}

O objetivo principal deste estudo in vitro foi o de verificar uma possível remineralização da dentina cariada humana. Trinta e nove dentes permanentes e deciduos recém-extraídos foram utilizados. Cada dente foi dividido em duas metades. Uma metade foi usada como controle e a outra como experimental. Nesta última, uma cavidade foi preparada e a camada remanescente de dentina desmineralizada capeada com hidróxido de cálcio quimicamente puro. As amostras experimentais foram armazenadas em estufa a $37^{\circ} \mathrm{C}$. Os períodos de observação foram de 2 , $4,6,8,10$ e 12 semanas. Todas as metades foram desgastadas até conseguir-se cortes plano-paralelos com espessuras variando entre 75 e $117 \mu \mathrm{m}$. Microradiografias qualitativas evidenciaram um aumento na radiopacidade das amostras tratadas com hidróxido de cálcio. A microradiografia quantitativa evidenciou um aumento estatisticamente significante no conteúdo mineral total nas amostras experimentais comparadas com as controles. Os resultados indicam uma remineralização in vitro da dentina cariada através do hidróxido de cálcio. 


\section{ACKNOWLEDGEMENTS}

The author wishes to express his recognition and gratitude to Professors Hilding Nyborg of the University of Umea (Sweden) and Sven Gottmar Ericsson of the University of Stockholm (Sweden), both deceased, for their scientific and technical contribution to this work and to the Swedish Agency for International Development (SIDA), the Brazilian Ministry of Foreign Affairs and the Faculty of Dentistry of Ribeirão Preto of the University of São Paulo on account of the grants awarded and financial support.

\section{REFERENCES}

1. Head JA. A study on saliva and its action on tooth enamel in reference to its hardening and softening. J Am Med Assoc 1912;59:2118-2122.

2. Conrado CA. Verificação da remineralização da dentina cariada tratada com hidróxido de cálcio quimicamente puro por meio da microradiografia qualitativa e quantitativa in vitro em dentes decíduos e permanentes humanos. [Post-Doctorate, Livre Docência thesis]. Ribeirão Preto: University of São Paulo, Brazil, 1994. 94 p.

3. Conrado CA. Verificação da remineralização da dentina cariada humana tratada com hidróxido de cálcio in vivo por meio da análise química de fósforo e microradiografias qualitativas e quantitativas. [Full Professor thesis]. Maringá: Department of Dentistry, State University of Maringá, Brazil, 1994. 146 p.

4. Law DB, Lewis TM. Effect of calcium hydroxide on deep carious lesions. Oral Surg Oral Med Oral Path 1961;14:1130-1137.

5. Palazzi S. Sur les mineralisation et remineralisation de la dentine. Bull Group Int Rech Sc Stomat 1966;9:257-266.

6. Fitzgerald M, Heyes RJ. A clinical and histological evaluation of conservative pulp therapy in human teeth. Oper Dent 1991;16:101-112.
7. Pereira JC, Berbert A, Segala AD. Long-term clinical and radiographic evaluation of teeth submitted to indirect pulp capping. J Dent Res 1997;76:179 (abstract).

8. Kato S, Fusayama T. Recalcification of artificially decalcified dentin in vivo. J Dent Res 1970;49:1060-1067.

9. Wefel JS, Harless JD. The use of saturated DCPD in remineralization of artificial caries lesions in vitro. J Dent Res 1987;66:1640-1643.

10. Tatsumi T. Physiological remineralisation of artificially decalcified monkey dentine under adhesive composite resin restoration. J Jpn Stom Soc 1989;56:49-74.

11. Gupta K, Tewari A, Sahni A, Chawla HS, Gauba K. Remineralizing efficacy of a mineral enriched mouth rinse and fluoridated dentifrice on artificial carious lesions: an in vivo scanning electron microscopic study. J Indian Soc Pedod Prev Dent 1998;16:67-71.

12. Thompson A, Grant LP, Tanzer JM. Model of assessment of carious lesions remineralization, and remineralization by a novel tooth paste. J Clin Dent 1999;10 (1 Special No):34-39.

13. Kardos S, Shi B, Sipos T. The in vitro demineralization potential of a sodium fluoride, calcium and phosphate ion-containing dentifrice under various experimental conditions. J Clin Dent 1999;10 (1 Special No):22-25.

14. Ericsson SG. Quantitative microradiography of cementum and abraded dentine: a methodological and biological study. Acta Radiol Suppl 1965;246:1-37.

15. Bergman G. Studies on mineralized dental tissues. XI Microradiography as a method for studying dental tissues. Odont Revy 1957;8:297-307.

16. Mjør IA. Histologic studies of human coronal dentine following the insertion of various materials in experimentally prepared cavities. Archs Oral Biol 1967;12:441-452.

17. Mondelli J. Proteção do complexo dentinopulpar. 1st edn. São Paulo: Artes Médicas, Série 1, EAP-APCD; 1998.

18. Koch G, Modeér T, Pousen S, Rasmussen P. Odontopediatria uma abordagem clínica. 1st edn. São Paulo: Livraria Ed. Santos 1992.

19. McDonald, RE, Avery, DR: Dentistry for the child and adolescent, 6th edn. St. Louis: Mosby; 1994.

20. Mathewson RJ, Primosch RC. Fundamentals of Pediatric Dentistry. 1st edn. Chicago: Quintessence Books; 1995.

Accepted January 29, 2003 